\title{
THE THUCYDIDEAN ELEMENT IN THE SPEECHES OF THE MYTILENAEAN DEBATE: HISTORY 3.37 - 48
}

\author{
R D Luginbill (University of Louisville, Kentucky)
}

The problem of defining the precise relationship between Thucydides' speeches and their exemplars has recently been characterized as "one of the central problems that confronts the ancient historian". ${ }^{1}$ It is true that in spite of generations of careful work, and despite Thucydides' own methodological comments which purport to explain the issue, the problem endures. ${ }^{2}$ Are the addresses bequeathed to us in the History essentially the historian's own handiwork, or are they, for all intents and purposes, accurate synopses of the actual speeches? Moderates in this debate may wish to note that proponents of both of the above positions generally have a foot in the other camp as well, the former being wisely unwilling to deny the speeches all historicity, the latter being warned by Thucydides' own words that verbatim accounts were impossible to obtain and reproduce (1.22.1), so that in this respect, at any rate, some consensus might be claimed. ${ }^{3}$ The exact point, however, at which the speeches depart from historical reality, or just what that element of non-reality or its purpose might be, continue to be matters of disagreement.

For those who are convinced of the high quality and accuracy of the History's narrative, and are yet at the same time sensitive to the prima facie literary problems involved in pronouncing the speeches genuine, the middle ground is all the more uncomfortable: where does one draw the line? For such persons, in the absence of a satisfying answer to this "central problem", the adoption of a largely agnostic attitude to the accuracy of the speeches has been a virtual necessity, if not a particularly satisfying solution. For those who resist seeing the speeches as either essentially accurate or essentially fictitious, clearing Thucydides of the charge of fabrication while at the same time making sense of what he has done and why, is a worthwhile task. Otherwise, we shall be left to fight the battle over historicity endlessly on each and every point, argument, and historical detail in each and every speech in the History, and that without a proper compass to guide us.

A quick perusal of the Demosthenic corpus and other surviving deliberative orations on the one hand, and of Thucydides' methodological paragraph on the other, can leave little doubt that the speeches in the History are not complete reproductions

\footnotetext{
Crane 1996: 66 n.60.

The explanation Thucydides gives for his compositional principles (paragraph 1.22) has only fueled the flames of controversy (see below). Bibliography on this longstanding question is extensive, to say the least, especially when one considers that general treatments on Thucydides inevitably deal with the issue, at least tangentially. Notable contributions that focus more or less narrowly on paragraph 1.22 include those by Debnar 2001:14-18, Winton 1999, Garrity 1998, Murari Pires 1998, Shrimpton 1998, Tsakmakis 1998, Wyatt 1996, Orwin 1994:207-212, Swain 1993, Badian 1992, Bicknell 1990, Woodman 1988:11-15, Hunter 1977, Kagan 1975, Dover 1973:26-27, de Ste Croix 1972:7-11, Winnington-Ingram 1965, and Gomme 1945, 1937. For earlier bibliography see Stadter 1973, and Luschnat 1970.

3 For example, Lattimore 1998:13 n, mentions Thucydides' "combination of summarizing and inventing".
} 
of the originals. ${ }^{4}$ Clearly, Thucydides has at least left some things out and suited the language to fit his own style. But as long as we can verify, first, that every speech conforms to an actual historical occurrence, and, secondly, that the "gist" (or $\xi \nu \mu \pi \alpha \sigma \sigma \alpha \gamma \nu \omega \mu \eta, 1.22 .1)$ of the historical speech is accurately reflected in Thucydides' composition, then only one serious obstacle remains to block our understanding and use of these speeches as legitimate historical documents, that is, the perplexing yet important question of how to determine just exactly what Thucydides has put in.

The hypothesis being advanced here is that Thucydides has taken genuine historical speeches, and recast them in his own language while preserving their theme and thrust, but has also added a significant amount of his own material. Specifically, this article will attempt to explore the single element which is completely Thucydidean, namely, a substratum of psychology that is common to all of the History's actors, individually and collectively, and that is intended to explain the historical process to the reader. Within these speeches, Thucydides has provided an explanatory element, based upon his own unique understanding of how human psychology operates in the historical process, and it is this material that disturbs the critic in us just as it entertains us in our capacity as readers. Defenders of Thucydides' historicity have tended to ignore the fact that this element has been added, while skeptics have tended to overreact to its inclusion. ${ }^{5}$ But by focusing on the uniquely Thucydidean layer in the History's speeches, it is possible not only to shed some light upon the particular purpose of this added psychological element, but also to form a clearer picture of what constituted the original subject matter with which Thucydides was working.

The Cleon-Diodotus antilogy seems a better place than most to analyze and demonstrate this principle. ${ }^{6}$ It is fair to say that perhaps no other two speeches in the History are more diametrically opposed on so many levels, seeming to constitute a veritable battle for the Athenian soul at a crucial point in the course of the Peloponnesian war, when, during its fourth summer (427 B.C.), the Athenians found themselves debating a plan to put to death all of the citizens of their newly recaptured rebellious city of Mytilene, with the otherwise unknown Diodotus arguing to save those whom Cleon, the leading political figure in Athens at that time, sought to destroy. ${ }^{7}$ Furthermore, Thucydides has been accused of harboring serious animus against Cleon, and in the case of Diodotus, of playing up his obscurity. ${ }^{8}$ Therefore,

4 Critics as early as Dionysius (De Thuc. 34ff.) and Cicero (Orator, 30-32) have complained about the artificiality of the speeches.

5 There are a variety of degrees of this, of course. See especially Pohlenz 1919, Strassburger 1958:17-8, Andrewes 1962:66-71, Flashar 1969:1-56, and Rood 1998:46-8.

6 Bibliography of note on this pair of speeches includes Andrews 2000, Debnar 2000, Tompkins 1993, Johnson 1990, Hussey 1985, Cogan 1981-2, Manuwald 1979, Macleod 1978, Kagan 1975, Schram 1965, Winnington-Ingram 1965, De Wet 1963, Andrewes 1962, Moraux 1954, and Bodin 1940.

7 Hussey 1985:129.

8 See Bowersock 1965:139, and Hornblower 1987:53 respectively. Hornblower 1991:423 notes the "curious but undeniable" aspect of Cleon's speech that there is much in it with which Thucydides agreed, despite his dislike for the man. 
whether this combination of factors is completely fictitious or completely devoid of Thucydides' own philosophy, we might expect it to lend itself both to maximum literary license and to stark differentiation between the parties.

Cleon's speech is brutal, vengeful, and pragmatic, and yet we do not find Diodotus opposing him with arguments based on the validity of Pericles' policy of non-expansion, or on the liability of empire, or on the advisability of making peace, or even - and this is perhaps the omission which seems most striking to the modern reader - on the ethics of proposing such a slaughter. Diodotus does not dispute Cleon's claim that the destruction of Mytilene is just, but rather that it is expedient (compare 3.40.4 with 3.47.5). Absent from both addresses, moreover, is the kind of detail in terms of references to events or any other specifics providing tangible proofs of the type we might well expect in speeches of this sort. Apart from the disparate solutions they propose, Cleon and Diodotus argue in essentially the same manner, and base their proofs upon a common set of principles. They each find expediency flowing from the same source, namely, an expected repetition of certain human behaviors which they understand and interpret in identical ways.

This identical substratum of psychology present in both speeches is uniquely Thucydidean. The overarching arguments, pro and con, may indeed be original to the historical debate (and we have little reason to believe in this case that they are not), but the extensive investigation of the human motivations upon which the expectations of future action are based, what hope and fear may bring among the allies in reaction to Athenian action, is unparallelled outside of Thucydides, and ubiquitous in Thucydides, in the narrative and in the other speeches as well (for hope see e.g., 1.70.7, 1.81.6, 2.62.5, 3.97.2, 4.17.4, 4.62.3, 4.65.4, 4.108.4, 5.103.6.15.2; 7.25.1, 8.2.4; for fear see e.g., 1.23.6, 2.65.9, 2.91.4, 3.83.2, 4.55.4; 4.125.1, 5.29.4, 6.49.2, 6.63.2, 7.21.3, 8.82.2).

Within this antilogy, therefore, we find both Cleon and Diodotus arguing from a common set of principles, Thucydidean principles. Both speeches base their proofs upon Thucydides' understanding of the nature of man and of the probable operation of the human psyche under pressure. As Wasserman has pointed out, no one could reasonably imagine any Athenian orator engaging in the sort of extensive discussion about human nature one finds in this antilogy and expect a patient hearing, let alone success. ${ }^{9}$ It is precisely this element, not merely the peculiarities of Thucydidean style, which would have put an audience off, so that as purely rhetorical compositions they are suspect. ${ }^{10}$ But these speeches are not meant to be models of rhetoric. They have been adapted by Thucydides not to persuade, but rather to explain and to educate. $^{11}$

On the surface of this antilogy, we find both Cleon and Diodotus presenting their points of view in a conventional manner. Neither Cleon's assault upon Athenian vacillation and the cloak of suspicion he attempts to throw over his opponent's motivations (3.37-38), nor Diodotus' defensive response - praising careful

\footnotetext{
9 Wassermann 1956:39. On the other hand, interest in psychological motivation is a distinguishing characteristic of Thucydides, as Huart 1968:2-4 has observed. On the abstract nature of the argumentation see Crane 1996:67. See Rutherford 1994 for bibliography and discussion of the educational element in Thucydides.
} 
consideration and recounting the dangers of chilling public discourse with such charges: 3.42-43 - comes as any particular surprise; such ploys may well have been usual fare (even if Thucydides' language presents these arguments as a sort of intellectual "concentrate"). Nor do the main arguments adduced by the speakers give us any reason to suppose that they are not original to the actual debate. Cleon claims that both justice and expediency argue for the destruction of Mytilene (3.40.4). Instead of appealing to pity and clemency to dilute Cleon's own appeal to justice, Diodotus argues that, in this case, carrying out Cleon's strict "justice" will prove inexpedient for the future (3.47.5). ${ }^{12}$ Even the main lines of discussion upon which these conventional arguments based on justice and expediency are developed are not particularly surprising. No one would be shocked to learn that Cleon argued for Mytilene's destruction as a penalty for her offenses, or that this would serve as an example to the other allies, nor that Diodotus had countered by claiming that the imposition of such a harsh penalty would only damage Athens by hurting her standing with the popular parties generally. After all, helping one's friends and harming one's enemies is the bedrock principle of classical Greek ethics. ${ }^{13}$ Indeed, with the benefit of hindsight, it is difficult to imagine such practical considerations being absent from this discussion, at least in some form. Yet both speeches have a decidedly Thucydidean flavor, and one that goes well beyond the issue of Thucydides' style. For it is not so much what Cleon and Diodotus argue that gives this antilogy its uniquely Thucydidean character, but how they make their arguments, namely, by appealing to the predictability of future historical behavior based upon an understanding of human nature that is more or less unique to Thucydides. ${ }^{14}$

But for whoever shall wish to have a clear view both of the events which have

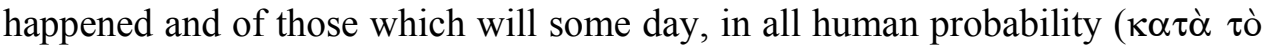
$\dot{\alpha} v \theta \rho \omega ́ \pi \mathrm{v} v v)$, happen again in the same or a similar way - for these to adjudge my history profitable will be enough for me (1.22.4). ${ }^{15}$

And so there fell upon the cities on account of revolutions many grievous calamities, such as happen and will happen while human nature is the same

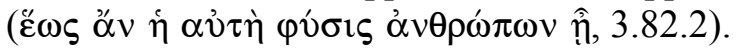

12 According to Kennedy 1963: 51, it is this "rejection of justice and appeal to reality" that gives the speech its main rhetorical force.

13 Cf. Dover 1974:180-184.

14 The paralleling of sentiments between the speeches and the narrative of the History is a phenomenon which has often been noticed and extensively discussed. See in particular de Romilly 1956, Andrewes 1962, Hunter 1973, and Macleod 1978. The point being demonstrated here is that Thucydides has his speakers argue their cases on the basis of his own unique system of psychology in order to help his readers view events in the light of these principles.

15 Quotations are from C.F. Smith's translation 1919. The phrase $\kappa \alpha \tau \grave{\alpha} \tau$ ò $\alpha \dot{v} \theta \rho \omega ́ \pi t v o v$ is a virtual

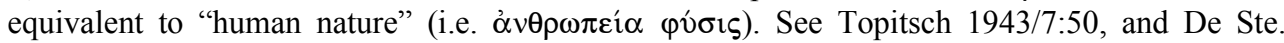
Croix 1972:29, for Thucydides' variable terminology for this concept. Cogan 1981-1:185ff.

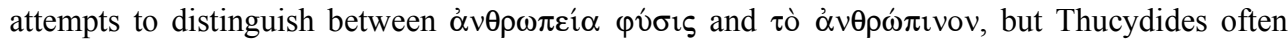
employs the neuter article with an adjective in place of an abstract noun, e.g., $\sigma \omega \varphi \rho o \sigma v ́ v \eta$ picked

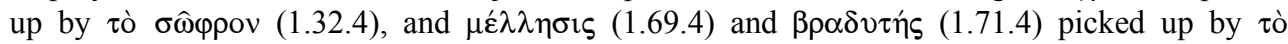
$\mu \varepsilon ́ \lambda \lambda o v$ and $\tau$ ò $\beta \rho \alpha \delta$ (1.84.1). 
Both Cleon and Diodotus base their cases upon just this same predictability of human behavior, that is to say, upon an understanding of human nature and how it operates collectively in the sphere of power politics, an understanding, moreover, that is taken to be common to themselves and their Athenian audience (and which also happens to be identical to that of Thucydides):

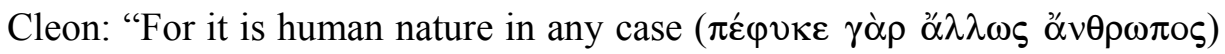
to be contemptuous of those who pay court but to admire those who will not yield." (3.39.5)

Diodotus: "In a word, it is impossible, and a mark of extreme simplicity, for anyone to imagine that when human nature is whole-heartedly bent on

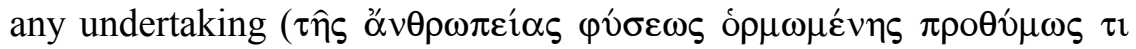
$\pi \rho \hat{\alpha} \xi \alpha l)$, it can be diverted from it by rigorous laws or by any other terror." (3.45.7)

In the context of their respective speeches, these statements are more than mere aphorisms, ${ }^{16}$ for they directly underpin the essential arguments of each of the speakers, with Cleon's analysis of human nature leading directly to the conclusion that a firmer hand will bring about the desired result of an empire less prone to rebellions, while Diodotus' similar appeal to human nature as the ultimate arbiter predicts entirely the opposite result and commends the opposite policy: harsh treatment of the sort proposed against Mytilene will not prevent future defections. Since both men are effective speakers (while Diodotus' proposal is carried in this case, Cleon is described in this very context by Thucydides as "most persuasive": 3.36.6; cf. 4.21.3), we must assume that Thucydides is presenting both of these foundational and seemingly contradictory statements about natural human responses as being equally true (or at least as received as being true by the Athenian audience who were equally divided on the issue at hand, only deciding against destroying Mytilene by the narrowest of margins: 3.49.1).

We do not, however, have here two antithetical and competing views of what human nature is really like. Instead, what we have are two polar opposite analyses of how human nature, commonly understood, will react in future circumstances. In other words, both men are applying an identical set of principles to the case before them, but are "spinning" these principles in a manner favorable to their respective positions. Not only is the basic understanding of human nature as it is developed and expressed in the respective speeches of Cleon and Diodotus essentially identical, but it is also substantially the same as that expressed by Thucydides elsewhere in the History. ${ }^{17}$ For it is just this element in both speeches that constitutes the "x-factor" added by Thucydides for his own educational purposes. Breaking down and explaining both present and, even more importantly, likely future circumstances in terms of this common, anticipated and predictable human behavior is at the core of what

16 What we have in this antilogy is not merely some variation of the traditional nomos-physis antithesis (wherein the rights of each element are opposed to each other). Indeed, with Diodotus' abnegation of the principle of law, there is barely any consideration of nomos as a counterbalance to physis at all; for the opposite view see Ostwald 1986:308. See also Meister 1955.

17

For example, $1.24 .4 ; 3.82 .2$. 
Thucydides means when he says that he has his speakers speak "how it seemed to me they would have been expressing the crucial issues" (1.22.1) - that is, had they had his insight into the true inner-workings of human nature and its effect on the historical process (and been disposed to express their points of view in these terms).

In order to demonstrate that Cleon's and Diodotus' casting of these events do demonstrate this precise point, it will first be necessary to consider briefly some specifics of Thucydides' psychological system and how they relate to the assumptions made by both of these speakers. ${ }^{18}$ Human behavior, especially group behavior, proceeds throughout the History according to a definite psychological system based upon certain hypotheses Thucydides had developed about the ways in which physis

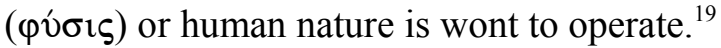

$\gamma \nu \omega ́ \mu \eta$ and ỏ $\gamma \gamma$ í: In Thucydides' system, gnome (mind) and orge (passion) do not so much represent two separate entities competing for domination of the human psyche as they do different aspects of physis. ${ }^{20}$ This explains why in studies of these concepts Thucydides is often regarded as characterizing physis as compulsive and malevolent, that is, because it includes orge as well as gnome and because it is more often than not orge that gets the upper hand in the struggle. ${ }^{21}$ For while it is certainly true that, at times in the History, gnome can represent the calculating side of man, and orge his impulsive side, it is also the case that Thucydides sometimes juxtaposes these two words as if there were little practical difference in the outcomes they produce. This is surely what we find in his comments concerning the stasis on Corcyra where we are told that men have "better gnomai" in times of peace, but that war "molds their orgai" to conform to its harsher circumstances (3.82.2). That is to say, under pressure gnome, rather than controlling orge, generally gives in to it as calculation comes to be governed by emotion. ${ }^{22}$

Scholarship on this issue has been, generally speaking, fairly uniform in recognizing this schism between gnome and orge in Thucydides' understanding of the human psyche, but also fairly consistent in underestimating the essentially emotional aspect of gnome as represented in the History in its frequent role of abettor in acquiring whatever men desire. ${ }^{23}$

18 For discussions of the elements of this psychological system, see Topitsch 1943/47:50-67, Müri 1947:251-275, and Luginbill 1999.

19 As is the case for all the concepts discussed in this section, Thucydides tends to use a diversity of vocabulary and modes of expression for the same or similar ideas. For this phenomenon in respect to human nature in particular, see de Ste Croix 1972:29, and see also Huart 1968:21, for Thucydides' use of synonyms in conceptual development.

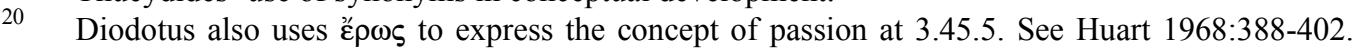

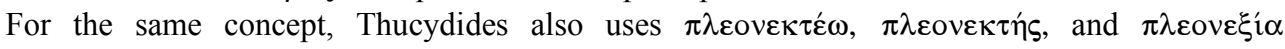

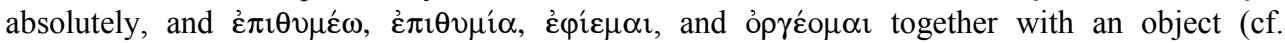
$1.128 .3,2.65 .10,3.84 .1,6.13 .3$, etc.).

$21 \quad$ See especially Nestle 1914:667ff.

22 Cf. 1.140.1, 2.59.1, 2.51.4.

23 Müri 1947:251-275; Huart 1968:54-57; Huart 1973:86-87; Schneider 1974:151; Edmunds 1975: 9-10; Connor 1984: 55, n.9; Schmid 1948:32-39. 
In Thucydides' system, orge represents man's motivational, impulsive side and gnome his perceptual, evaluative side ${ }^{24}$. Moreover, these two facets or aspects of physis are often seen to work together in the History in quite close conjunction. When motivated to act by orge in any of its iterations (acquisitiveness, love, hate, anger, etc.), it is gnome's role to analyze the obstacles which stand in the way of satisfying these impulses. In Thucydides' system, the orge part of man's essential nature (his passion) urges him on, while the gnome part (his mind) - though it does reflect and deliberate, sometimes approving and facilitating, sometimes rejecting the demands of orge - does not necessarily guide him in anything like what we might call an unemotionally calculating way. For most of the History's actors, individually and collectively, at most times and in most instances, gnome tends to base its evaluations on subjective and emotional criteria. It is prone to error, giving more heed to the passions it serves than to any objective analysis (let alone any higher purpose), and it is precisely for this reason that Thucydides felt that the process of history was likely to continue on its impulsive way "as long as human nature stays the same" (1.22.4; cf. $3.82 .2){ }^{25}$ This conviction, somewhat provocative even to modern, skeptical sensibilities, can hardly have been anything like a uniform point of view in fifthcentury Greece, but both Cleon and Diodotus are seen to advance it to their Athenian listeners as if it were:

Diodotus: "All men are by nature prone to err ( $\pi \varepsilon \varphi v ́ \kappa \alpha \sigma \imath \dot{\alpha} \mu \alpha \rho \tau \dot{\alpha} v \varepsilon \imath v)$, both in private and in public life, and there is no law which will prevent them." (3.45.3)

Cleon: We must not, therefore, hold out to them any hope, either to be secured by eloquence or purchased by money, that they will be excused on the plea that their error was human $(\dot{\alpha} \mu \alpha \rho \tau \varepsilon \hat{\imath} v$

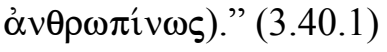

While both Cleon and Diodotus make use of Thucydides' notion of unchangeable human nature to buttress their arguments, each puts his own self-serving twist on the principle. Diodotus presents the predictability of historical action "according to the

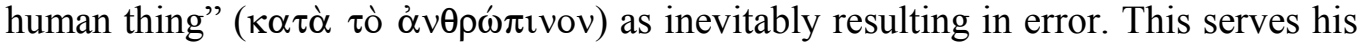
purpose well in the debate, for, if error is inevitable, then by definition it cannot be prevented. Since no terror can prevent similar rebellions, making an example of Mytilene is pointless (and will be harmful). Cleon's statement to the effect that human error must not be held out to the rest of the allies as a plausible excuse, in his view the precise result, in effect, of pardoning Mytilene, assumes prima facie that holding the Mytilenaeans responsible will indeed have a deterrent effect on the future behavior of the allies.

24 The impulsive side of physis as represented by orge and its related verb (ỏ $\rho \gamma \alpha \omega)$ can be seen at 2.21.3, 2.22.1, 3.45.4, 4.108.6, and 8.2.2.

25 The importance of physis in the History in this regard is discussed by Finley 1947:109, Schmid 1948 pt.1, v.5, 36-37, Pouncey 1980: 20ff., Hunter 1982: 173ff., and Reinhold 1985:23. 
Both positions are extreme generalizations. They are also both oversimplifications of Thucydides' system of group psychology. Diodotus' interpretation suggests that physis is virtually incapable of being influenced by outside forces (at least when it is "wholeheartedly bent" on anything: 3.45.7), something we as readers understand immediately is not entirely true of the History's action. Even if human nature individually, and in its aggregation into national character, does prove resilient, it is not immune to outside forces. While it certainly is possible to adduce examples where Thucydides' comments may seem to support Diodotus' interpretation (the uncontrollable Athenian enthusiasm for the Sicilian operation, 6.24.2, and the ebullient allied response to Brasidas' success, 4.104.8, to name but two), there are also plenty of occasions on which we are told that adventurous behavior was, in fact, restrained (for example, excessive Spartan timidity following their run of defeats during the first part of the war, 4.55.2-4, and Pericles' ability to rein in Athenian exuberance, 2.65.9).

Cleon's contention, implicit in the remark quoted above, is explicitly expanded at the conclusion of his speech when he urges his countrymen to make "an example" ( $\pi \alpha \rho \alpha \delta \delta \varepsilon \imath \gamma \mu \alpha)$ of Mytilene to the rest of Athens' allies, promising them a reduction in the problem of rebellions as a result (3.40.8). In Cleon's interpretation of the same general principle of universal human nature resulting in predictable future modes of behavior, particular action will have a definite and anticipated result. Physis can be influenced in a predictable way. This is the first in a long list of ironies which Thucydides has Cleon commit, for as every reader of the History knows full well, plans do not always work out in the expected way, and that is especially so when, instead of encompassing concrete present problems for which sufficient resources are at hand, they involve unknown and unknowable future situations. ${ }^{26}$

To hear Diodotus tell it, there is, in effect, no reliable evaluative process that weighs the risks when something is desired (i.e., gnome always responds positively to orge, in spite of circumstances), whereas, according to Cleon, providing a harsh demonstration of the risks involved will produce a corresponding correct evaluation of the true circumstances (i.e., gnome can be relied upon to resist orge in a reasonable, predictable way). These two polar opposite applications of the same underlying principle, namely, that consistent human nature produces repetitive historical behavior, are also evident in the way Thucydides has each speaker employ gnome and orge (and their synonymous referents).

Thucydides tells us that the original decree to destroy Mytilene was made under the influence of anger ( $\dot{v} \pi^{\prime}$ o $\rho \gamma \hat{\eta} \varsigma, 3.36 .2$ ), ${ }^{27}$ and Cleon is clearly sensitive to this, using orge directly only once at the beginning of his speech to note how the passage of time blunts it to the victim's disadvantage (3.38.1). Therefore Cleon's speech emphasizes gnome instead, especially in his criticism of his fellow Athenians

26 Thucydides' praise for the carefully planned breakout from Plataea (3.20-24), and his censure of the disastrous Sicilian expedition (2.55.11-12) are perhaps the History's clearest examples of what he considered proper calculation and gross miscalculation respectively.

27 A common manifestation of human nature's impulsive side as mentioned above (6.57.3; cf. 2.11.7, 6.60.2). Along with, e.g., shame (5.104), and hatred (1.96.1), these emotions, while somewhat different in their character from passion per se, also motivate action. 
$(3.37 .3,3.37 .4,3.38 .2,3.38 .6)$ and his recommendation of his own sagacity and consistency $(3.37 .1,3.38 .1)$. For him, the proper evaluation of this situation is for the Athenians to give vent to the orge they originally felt. At 3.40.7, he essentially equates the two, advising his listeners not to betray themselves but to hold fast to their decision, the gnome they had at the point of suffering, that is to say, their original

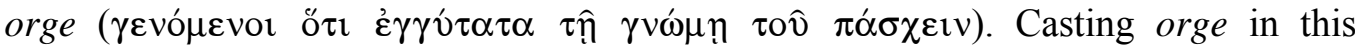
positive, calculating light clearly gives a measure of cover to those who think as he does, while at the same time suggesting that it is those who wish to reverse the measure who are guilty of giving in to emotion.

It is only when the allies come fully to know what awaits them if they revolt (through the example of Mytilene) that Athens can expect relief from rebellions of

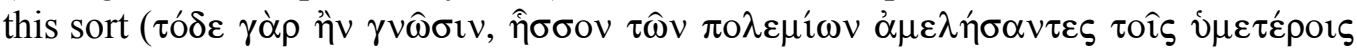
$\alpha \hat{\tau} \tau \hat{\omega} \nu \mu \alpha \chi \varepsilon \hat{\imath} \sigma \theta \varepsilon \xi \xi \mu \mu \alpha ́ \alpha 01 \varsigma, 3.40 .8)$.

Thucydides also has Diodotus tie directly into his analysis that orge was responsible for the first, harsh decree. Diodotus finds it understandable that his hearers might think Cleon's advice good, but only because they are under the

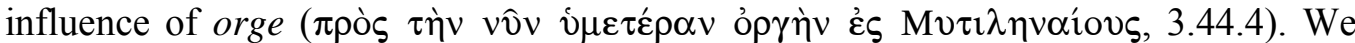
are thus not surprised to find Diodotus contrasting orge with gnome to the detriment of the former, precisely because it is identified with Cleon's plan in a sort of "guilt by association" argument: to the extent that Cleon's advice conforms to orge, it must be bad advice. According to Diodotus, orge and swift action (a corollary effect of

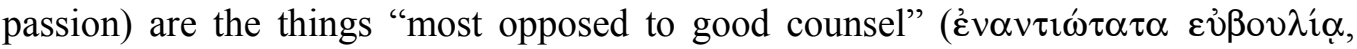
3.42 .1 , where euboulia stands as a veritable euphemism for gnome. ${ }^{28}$ Within his somewhat lengthy scolding of his fellow Athenians for the counterproductive way in which they treat their counselors, orge and gnome play significant roles, with the former representing the unreasonable (and unintelligent) attitude of the public, and the latter closely linked to the speakers who mean Athens only good ( $\pi \rho$ ò

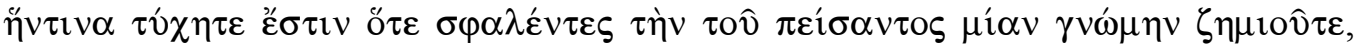
3.43.5; cf. 3.42.5, 3.42.6). Diodotus is thus wrapping himself and his argument in

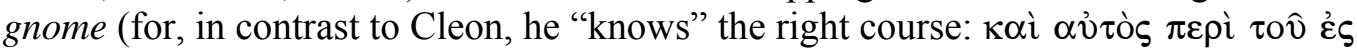

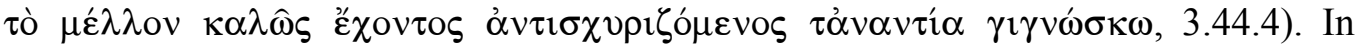
doing so, he is taking all deliberation as necessarily intelligent and yielding success, whereas any plan begotten in a state of orge must, for that reason, be faulty. As readers, we are aware that in Thucydides' narration of events even careful plans can

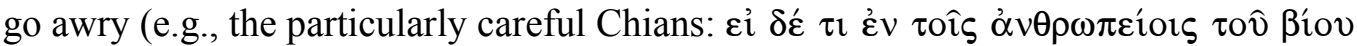

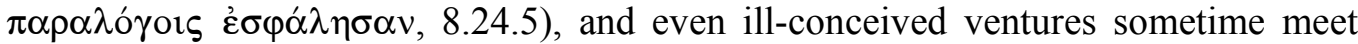

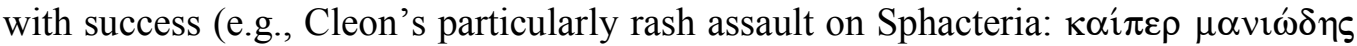

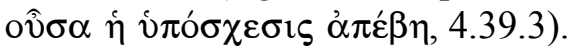

More than this, there is a large sense in which the reliance of Diodotus' argument upon gnome is in its own way just as ironic as that of Cleon upon the predictability of future behavior. ${ }^{29}$ For Diodotus' logic is built upon the proposition that men, because of the impetuousness of their nature, cannot be restrained by

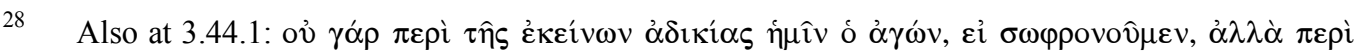

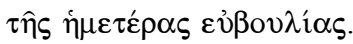

29 See Debnar 2000:170-172, and Manuwald 1979:410. 
example, which is to say, they cannot (or will not) learn the lesson which Cleon desires to teach Athens' allies. But if that is so, how, then, is it that they most certainly will be responsive to the unintended pedagogy of Mytilene's fate? This is Diodotus' position, and he puts it in terms of gnome. When they realize the new

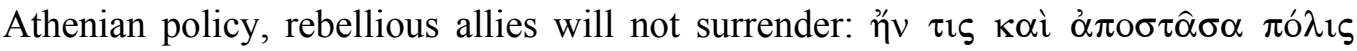

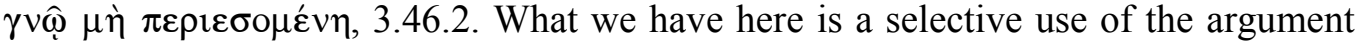
from physis which presents human nature as governed by emotion and incapable of restraint only when it is operating out of an active passion or orge (i.e., acquisitiveness), but not when it is being influenced by a passive one (i.e., fear of consequences). Even more ironic, of course, is the fact that Diodotus will succeed in doing just what he has proclaimed impossible, namely, restraining the orge of the Athenians by instilling in them a level of trepidation about the consequences of such a brutal act (in direct contradiction to the irresistible nature he claims for orge at 3.45.4:

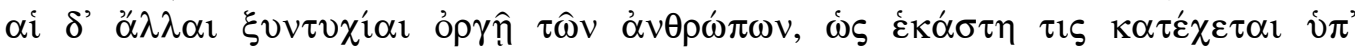

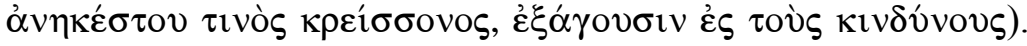

Despite Cleon's contention that orge in this case is reasonable, and Diodotus' appeal to gnome (which is at the same time based upon the underlying emotion of Athenian regret as well as twisted argumentation), both speakers are making use of the concept of orge as an emotional motivator, and gnome as its conscious interface. While each man utilizes these ideas to his own rhetorical benefit, both are nonetheless accepting and, we may say, promulgating Thucydides' system of psychology.

$\dot{\varepsilon} \lambda \varepsilon v \theta \varepsilon \rho i \alpha$ and $\alpha \rho \chi \eta \dot{n}$ : While orge and gnome constitute the essential architecture of human nature on the individual level in Thucydides' system, freedom (independence for oneself from the control of others) and empire (control of others for the benefit of oneself) are the two prime manifestations of physis in the assertion of that primal force in group behavior. Thucydides understood that the collective orge of a people, whether momentarily defined in terms of material acquisition, honor, vengeance, or in any other way, can best be satisfied through dominance over others (practical considerations aside). Similarly, the loss of what has already been achieved and the threat of like depredations against themselves can best be avoided by the maintenance of freedom from the domination of others.

Perhaps the clearest demonstration of this principle comes early in the History in Thucydides' description of proto-Greek history:

For it is plain that what is now called Hellas was not of old settled with fixed habitations, but that migrations were frequent in former times, each tribe readily leaving its own land whenever they were forced to do so by any people that was more numerous. (1.2.1)

Here we see both sides of the axiom at work, with some groups maintaining their independence by abandoning their rudimentary settlements, while others, more powerful through superior numbers, dispossess them and take control in turn. When emigration on the mass or individual level is no longer a viable option, the more powerful tend to exert their will over the weaker, and it is precisely this drive to dominance that Thucydides saw as the force responsible under the surface for the horrendous developments at Corcyra (3.82.8). The matter-of-fact way in which 
Thucydides characterizes Xerxes' motivation for invading Greece in just these terms (i.e., "to enslave" it: 1.18.2) is also indicative of the universality he saw for this principle (especially in contrast to Herodotus' much more elaborate explanations), and it is in just such a matter-of-fact way that Thucydides has the Athenians put this very principle to the Melians who are told that "the powerful exact what they can and the weak yield what they must" (5.89).

This principle, a given in the History, finds perhaps its clearest expression in the speech of the Athenian ambassadors to Sparta in the days before the war, in the remarks of Hermocrates at the Gela conference, and in the pronouncements of the Athenian representatives at Melos. It is a principle which in all three cases is carefully tied by Thucydides directly to human nature: ${ }^{.0}$

The Athenian ambassadors: "Thus there is nothing inconsistent with human

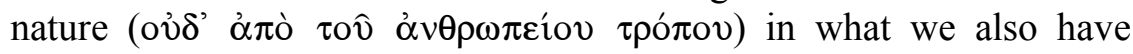
done, just because we accepted an empire when it was offered us, and then, yielding to the strongest motives - honour, fear, and self-interest, declined to give it up." (1.76.2)

Hermocrates: "And I have no word of blame for those who wish to rule but for those who are too ready to submit; for it is an instinct of man's

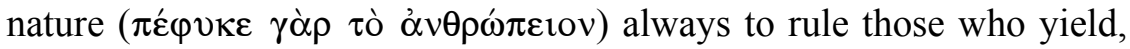
but to guard against those who are ready to attack." (4.61.5)

The Athenians at Melos: "For of the gods we hold the belief, and of men we

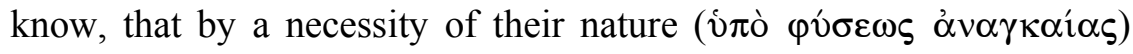
wherever they have the power they always rule." (5.105.2)

From the point of view of subject (potential subject) states where there can be no question of ruling others, freedom is the first and fundamental concern:

The Melians: "Surely, then, if you and your subjects brave so great a risk, you in order that you may not lose your empire, and they, who are already slaves, in order that they may be rid of it, for us surely who still have our freedom it would be the height of baseness and cowardice not to resort to every expedient before submitting to servitude." (5.100)

Because the case in hand is that of a rebellious ally, Cleon and Diodotus naturally concentrate primarily upon this more passive side of collective physis (i.e., the desire to be free of the rule of others irrespective of the desire to rule over others) in their interpretation of events, and there is no lack of passages in the History which support this side of the principle as equally axiomatic (e.g., 4.92.3-4, 5.89, 6.20.2, 7.65.2, 8.64.5). What is significant in this debate is the way in which each speaker uses the corollary to his own advantage:

30 Archidamus' comments on Athenian behavior at 2.11.8 likewise imply that the desire to rule over others is, to some degree, universal (2.11.8). Compare de Romilly's first two "laws" of imperialism 1963: 311-36. For the consistency of such motivation in the History's actors see also Thompson 1969:138ff. 
Cleon: "Consider, moreover, your allies: if you inflict upon those who willfully revolt no greater punishment than upon those who revolt under compulsion from our foes, which of them, think you, will not revolt on a slight pretext, when the alternatives are liberty if he succeeds or a fate not irreparable if he fails?" (3.39.7)

Diodotus: “. . . and states even more than men [are prone to take unreasonable risks], inasmuch as the stake is the greatest of all - their own freedom or empire over others - and the individual, when supported by the whole people, unreasonably overestimates his own strength.” (3.45.6)

Thus for Diodotus, the collective orge of any people will automatically express itself in an unrestrained and irrepressible rush to freedom, whereas in Cleon's estimate, it will only be the very lack of fear occasioned by failure to implement his proposal that will stimulate others to revolt. Each man projects the future internal deliberations of hypothetical allies in a way that supports his own point of view. According to Diodotus, there will simply never be to all intents and purposes a situation where corporate gnome will take into account the dangers involved in revolt and so act to dissuade a potential future rebellion. On the other hand, we can deduce from Cleon's comments that he takes it for granted that the destruction of Mytilene will have just such a chilling effect. In other words, the aggregate gnome of any individual state so inclined will of course take Mytilene's example to heart. As readers, through the perspective Thucydides has given us, we understand that the fear of destruction and the hope of freedom are both powerful forces deep-set in the nature of man, and that neither would necessarily hold sway over the other should they come into direct conflict as here. Given the predisposition of men to make mistakes in such calculations and the incalculable nature of future situations, neither Cleon nor Diodotus can guarantee that his interpretation of the future behavior of hypothetical parties will be as advertised. As we have seen, gnome is, for Thucydides, a fickle thing of which the emotional reactions are difficult enough to predict in known situations, let alone in theoretical ones.

Just as both Cleon and Diodotus were seen to use the concept of physis and its two essential aspects of orge and gnome not only to analyze the political situation at hand but also in a rhetorical way to influence their audience, so here too we see Thucydides framing their respective appeals in terms of the subjective application of $\dot{\varepsilon} \lambda \varepsilon v \theta \varepsilon \rho i \alpha$ and $\alpha \rho \chi \eta \dot{~(i n ~ a d d i t i o n ~ t o ~ t h e ~ o b j e c t i v e ~ a n a l y s i s ~ d i s c u s s e d ~ a b o v e) . ~ C l e o n, ~ i n ~}$ his attempt to convince his countrymen of the need for drastic measures, stresses what he sees as the unrealistic Athenian point of view, namely, to possess an empire but at the same time fail to appreciate its true nature and the inevitable consequences of enslaving others. The Athenians do not appreciate the fact that their arche is a "despotism", and they fail to see that they cannot deal with their subjects in the same open and easy way that characterizes their internal relationships (3.37.2).

They are prone to pity, to clemency, and to abandoning necessary imperial policy out of delight for a well-delivered speech (3.40.2). All of these things endanger the safety of an empire which by definition dominates others who by nature would 
rather be free (3.39.7). For this reason, democracy is ill-suited for rule over others (3.37.1). The collective effect of these sentiments is to generate in the Athenian audience a fear of failing to instill sufficient fear in their subject populations, so that we here see Cleon playing the role of Athens to the allies in his attempt to cow his audience as he would have Athens do her subject states.

Diodotus, on the other hand, seeks to relieve the consciences of his fellow citizens by advocating a policy of magnanimity as being in Athens' true interest (3.46.5-6). Having argued for the inevitability of future rebellions, he can only offer the hope of more speedy resolutions by not cutting off the hope of those who revolt (3.47.1-3). Submitting to be wronged by those they rule is, somewhat paradoxically, the best way to maintain that rule (3.47.5), and just so Diodotus pleads with his hearers to yield to him for their own good just as he would have them yield to their allies for the good of the empire.

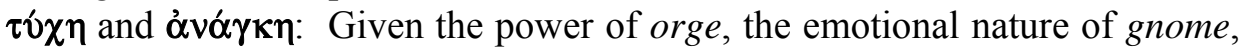
and, in group behavior, the expression of this fundamental architecture of physis in the universal human desire for freedom and the domination of others, it is fair to ask why, in Thucydides' understanding of things, states are ever at peace. The answer to this question is to be found - again according to the system of human group behavior advanced in the History - in the external considerations which affect gnome, individually and collectively, namely, chance (tyche) and necessity (anangke). Emotional, subjective, and prone to error though it is, the perceptive side of man, gnome, is well aware of the dangers involved in satisfying orge's every whim. The uncertainty of success in any endeavor is represented in the History by tyche, the principle of the unpredictable and the unexpected. Dangers and opportunities respectively dissuade and encourage action by individuals and groups alike as each calculates the risks and benefits of any given undertaking. That is not to say that this is an accurate or an objective process, for gnome often errs, and tends to predict the future from the standpoint of past experience. Thus the History's actors, individual and collective, are sometimes discouraged from opportunities by assuming unfavorable luck will again befall them, and are just as often led into taking poor chances by relying too heavily upon previous good luck (a phenomenon which Thucydides explicitly cites in regard to the Spartans and Athenians):

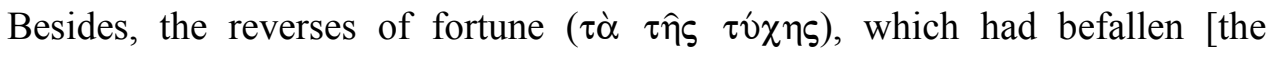
Spartans] unexpectedly in such numbers and in so short a time, caused very great consternation, and they were afraid that some time a calamity might again come upon them like that which had happened on the island; and on this account they showed less spirit in fighting, and whatever move they might make they thought would be a failure, because they had lost all self-confidence in consequence of having been hitherto unused to adversity. (4.55.3-4)

To such an extent, because of their present good fortune ( $\tau \hat{n} \gamma \varepsilon \pi \alpha \rho o v ́ \sigma \eta ̣$

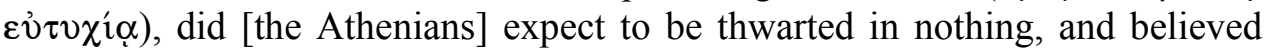
that, no matter whether their forces were powerful or deficient, they could equally achieve what was easy and what was difficult. The cause of this was the amazing success which attended most of their undertakings and inspired them with strong confidence. (4.65.4) 
In both of these descriptions given by Thucydides, the power of tyche to influence group behavior is especially evident in the development of events contrary to expectations. The potential dangers arising from this "fickleness of fate" is also appealed to by both Cleon and Diodotus in support of their respective points of view:

Diodotus: "Besides these, fortune ( $\dot{\eta} \tau \hat{v} \chi \eta)$ contributes in no less degree to urge men on; for she sometimes presents herself unexpectedly and thus tempts men to take risks even when their resources are inadequate ..." (3.45.6)

Cleon: "And indeed it is the rule, that such states as come to unexpected prosperity most fully and most suddenly, do turn to insolence, whereas

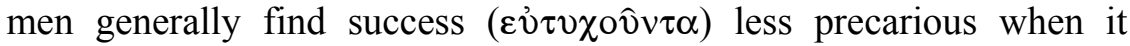
comes in accordance with reasonable calculations than when it surpasses expectation, and more easily, as it seems, they repel adversity than maintain prosperity." (3.39.4)

Since Mytilene has been found guilty of trusting too much to chance and acting as a result in an ill-advised way (after the pattern of the Athenian example given above rather than that of the Spartans who were led to inaction by their negative experiences), both speakers approach the issue of tyche from the standpoint of its seductive qualities. In Diodotus' appreciation of the issue, tyche's historical role is simply and straightforwardly to entice individuals and groups into taking risks. Thus, in addition to the irresistible internal forces of human nature, the external forces which act upon physis are ever pushing in the same direction (a coalition of circumstances that make rebellions inevitable). Because of the specific circumstances at hand, Cleon also mentions the tendency of unexpectedly favorable tyche to produce poorly conceived ventures, but his somewhat similar interpretation of this same principle is significantly different: the Athenians should not, therefore, have given Mytilene special favorable treatment in the first place (a factor in his analysis contributing to their hybris: 3.39.5), and should correct their error now by applying fitting punishment (3.39.6). The good fortune received by Mytilene at Athens's hand has only had the effect of vitiating the lesson they should have learned by observing their neighbors' fates in similar circumstances (3.39.3). While Cleon accepts the principle of favorable tyche's potentially powerful seductiveness, implicit in his argument is the corollary principle of the chilling effect of unfavorable tyche, a force which may only be brought to bear if Athens sends the right message here (3.39.7). Should the Athenians fail to take his advice, they can expect all of their allies to revolt even on the smallest pretext, thus expanding their own level of "risk", and

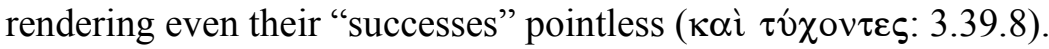

In the case of anangke, Thucydides' second external principle which pressures physis, we find a similar concentration upon its motivational (as opposed to its dissuasive) power. While necessity is often a force which retards action (when respective sides are roughly equal; cf. 5.89), in respect to its ability to produce risktaking we are reminded of Thucydides' analysis of the overall cause of the war: 
The truest explanation, although it has been the least often advanced, I believe to have been the growth of the Athenians to greatness, which brought fear to the Lacedaemonians and forced ( $\alpha v \alpha \gamma \kappa \alpha ́ \sigma \alpha l)$ them to war. (1.23.6)

For Diodotus, necessity is an additional accelerator to bold action in cases of penury. He lays none of his argument's weight upon necessity - anangke is merely part and parcel of the interaction of physis with history which always produces similar results:

Diodotus: "Nay, men are lured into hazardous enterprises by the constraint

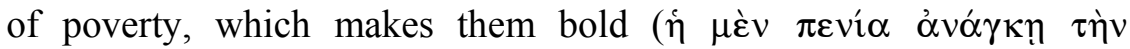

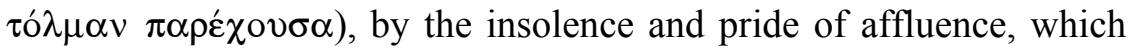
makes them greedy, and by the various passions engendered in the other conditions of human life as these are severally mastered by some mighty and irresistible impulse." (3.45.4)

This omission is not at all surprising given Mytilene's privileged position within the empire and Cleon's prior hammering home of the lack of necessity for this rebellion on her part $(3.39 .2,3.39 .7,3.40 .3)$, a point which Diodotus does not attempt to refute directly. Cleon's acceptance of anangke as an understandable motivation for revolt has the twofold effect of branding Mytilene's actions as inexcusable on the one hand, and suggesting that a failure by the Athenians to make the distinction between rebellions engaged in under duress, and those upon which necessity did not weigh, will only produce more such revolts in the future. Furthermore, since anangke is absent as a motive for Mytilene's rebellion, failure to destroy her will only make her a more dangerous enemy in the future:

Cleon: "Indeed, it is generally those who wrong another without cause that follow him up to destroy him utterly, perceiving the danger that threatens from an enemy who is left alive; for one who has been

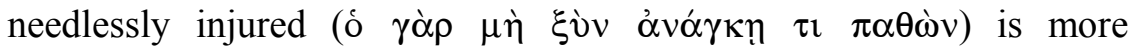
dangerous if he escape than an avowed enemy who expects give and take." (3.40.6)

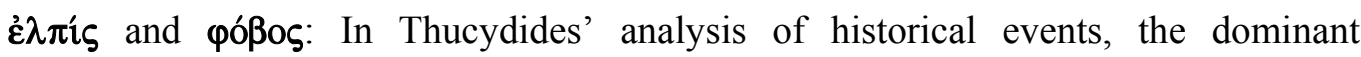
psychological state of the individual or group in question at the time of action and deliberation is always important. While tyche and anangke represent the external pressures which affect gnome's deliberations, the combined effect of recent experiences inevitably produces a psychological disposition within the individual concerned toward action or inaction depending on whether recent events have been favorable or unfavorable. A string of successes or other favorable circumstances generally produce the disposition of hope, while repeated setbacks or other disadvantages, as a rule, engender fear (as in the case of the Athenians and Spartans quoted above). While individuals with exceptional courage or a state with prudent leadership might avoid the pitfall of inaction through fear regardless of circumstances, or of undertaking inordinate risks in spite of their inadvisability, for most in the History the decision to act or not is in fact determined by the predominating psychological disposition of the moment, whether of hope or of fear. 
Critical to the reasoning behind the proposals of both Cleon and Diodotus is their prediction of future behavior on the part of the allies as a result of their respective policies, and each makes full use of this fundamental Thucydidean principle. Diodotus' long disquisition on human nature has as its goal the conclusion on the part of his audience that hope is irrepressible (and therefore rebellions inevitable):

Diodotus: "Then, too, Hope and Desire are everywhere; Desire leads, Hope attends; desire contrives the plan, Hope suggests the facility of fortune; the two passions are most baneful, and being unseen phantoms prevail over seen dangers." (3.45.5)

In this short synopsis Diodotus presents orge, desire (or passion), as colluding with hope in running roughshod over gnome, with all dangers ignored and good luck assumed. Fear is entirely absent as a consideration or a possible alternative attitude here, regardless of circumstances. For Diodotus, it would be necessary to invent something more frightening than death itself in order to prevent future rebellions (3.45.4). The only effect of Cleon's policy, in his view, will be to remove all hope from rebels once they do revolt, giving them the courage of desperation which is much against Athens' interests (3.46.1). Diodotus is not above using the principle of fear's chilling effect in his remonstrances against those like Cleon who impugn the motives of other speakers (3.42.4-5), but his analysis of probable future behavior among the allies entirely ignores its potential to produce paralysis. Paradoxically, he maintains that his policy which eschews reliance upon fear and gives hope of reconciliation to future rebels will be "fearsome" to Athens' enemies (3.48.2).

Cleon, on the other hand, believes the main problem with the Mytilenaeans to be precisely that they have not felt a sufficient degree of trepidation on account of their privileged status within the empire:

Cleon: “... but [these were] men who inhabited a fortified island and had no

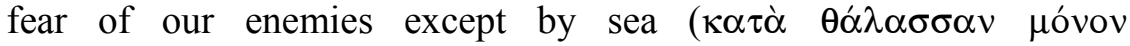

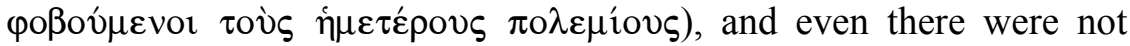
without the protection of a force of their own triremes, who moreover were independent and treated by us with the highest consideration ..." (3.39.2)

This prior treatment of Mytilene is an example, in Cleon's opinion, of the Athenians' unwise application to their imperial policy of the lack of fear they enjoy internally ( $\tau$ ó

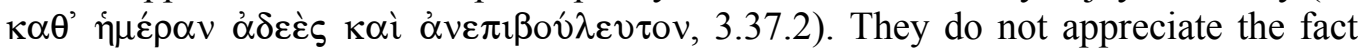

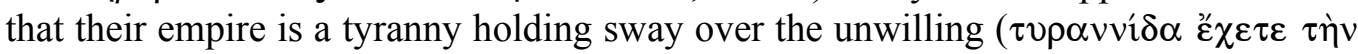

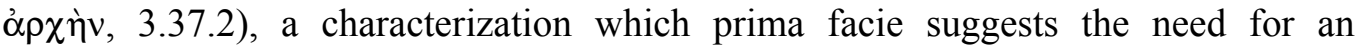
adequate level of terror to maintain it. In Cleon's analysis, the adoption of his advice will render the Mytilenaeans an exception rather than the rule. They failed to take proper counsel of what should have been legitimate fears (arising from observing the fate of others) only because of Athenian pampering (3.39.3). They conceived hopes

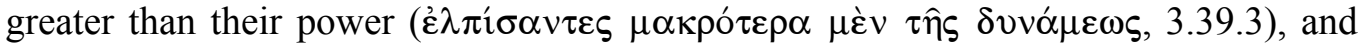

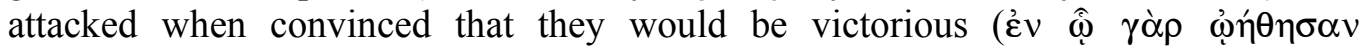


$\pi \varepsilon \rho \varepsilon \varepsilon \sigma \varepsilon \sigma \theta \alpha 1,3.39 .3)$. This is not, in Cleon's estimation, the inevitable scenario Diodotus would make it. Mytilene's privileged treatment and Athenian failure to take firm measures inspired her hopes. What is necessary to ward off future rebellions is, in Cleon's view, the removal of all hope for future clemency in similar situations (3.40.1). Just as Diodotus' use of the dispositions of hope and fear presents a onesided picture, so in Cleon's analysis dissuasion of future insurrections is a simple (and predictable) matter of increasing the level of terror.

Thucydides' own view of the psychological mechanics of hope and fear in a similar context can best be seen from his description of the reasoning of the Athenian allies who revolted to Brasidas:

For it seemed to them that there was little ground for fear, since they estimated the Athenians' power to be far less great than it afterwards proved to be, and in their judgment were moved more by illusive wishing than by cautious foresight; for men are wont, when they desire a thing, to trust to unreflecting hope, but to reject by arbitrary judgment whatever they do not care for [emphasis added]. (4.108.4)

In this analysis, fear has been an effective restraint up to this point. In order for gnome to shift towards a more hopeful mode, fear must first be removed, in this instance through a combination of Brasidas' successes and a concomitant underestimation of Athenian strength. Based upon this parallel given in Thucydides' own voice, it would seem that Cleon and Diodotus have each presented but half of the truth. Hope (of freedom) is ever bubbling beneath the surface, ready to burst forth, but a seemingly suitable opportunity must first present itself to change the underlying psychology.

The extensive use of an identical theory of human behavior by both Cleon and Diodotus enables us to take Wasserman's conclusion one step further: not only is it unlikely that an individual speaker in the assembly could delve so deeply into psychological analysis and still expect a hearing, but it is practically inconceivable that the advocates of both sides of such an important issue might do so - what we have here lies far beyond any rhetorical benefit from specific response to one's points. ${ }^{31}$ This is especially so when one considers that both Cleon and Diodotus are basing their arguments on an identical theory, and that, while they "spin" the application of its principles in their own direction for rhetorical effect, their understanding of these matters is identical to that of Thucydides. Insofar as these two speakers have expressed and argued from Thucydides' unique theory of physis and its implications for historical behavior, there can be little question that these ideas and arguments are Thucydides' alone.

Once it is accepted that it is this theory of psychological mechanics - a theory which permeates the History - that constitutes the Thucydidean element in the speeches, several further conclusions may be drawn. First, this has obvious application to the question of how much and what of the speeches should be taken as historically accurate. As with his explication and analysis of the psychological

$31 \quad$ Wasserman 1956:39. 
motives of individuals at various point in his narrative (e.g., Demosthenes: 3.97.2), it is not that Thucydides has changed the facts, but that he placed these facts within an interpretive framework that conditions our reception of them. The addition of this psychological, analytical framework has, in this writer's view, been at the heart of much of the skepticism leveled at the historical accuracy of Thucydides' speeches. Recognizing this interpretive element for what it is, we may place just as much confidence in the factuality of the other information in the speeches as we do in any

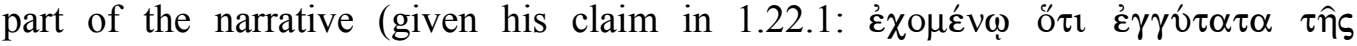

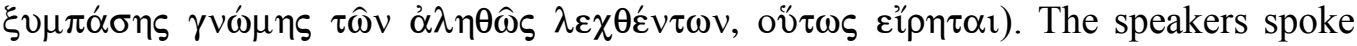
what they did, but Thucydides, in addition to sticking close to the gist of the speech (i.e., the $\xi \nu \mu \pi \alpha ́ \sigma \alpha \gamma \nu \omega \dot{\mu} \eta)$, also includes what they should have said or would have

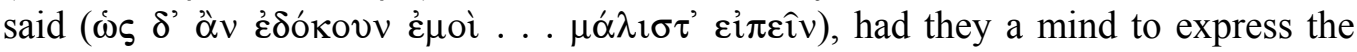
true underlying psychological realities of the situation upon which the historical action turned (i.e., $\tau \dot{\alpha} \delta \dot{\varepsilon} o v \tau \alpha)$. In paragraph 1.22, Thucydides has alerted his readers in advance to his intended inclusion within his speeches of this element not present in those actually delivered at the time, and the antilogy of Cleon and Diodotus is sufficient to prove the presence of this element.

Secondly, if it be accepted that Thucydides' methodological statements put him on record as having deliberately included this interpretive psychological element in the speeches, then it is no great leap to assume that this device is somehow supportive of his overall purpose expressed later in the same paragraph, namely, to benefit his readers by uncovering for them the true reality that underlies historical events (i.e., $\tau$ ò $\sigma \alpha \varphi \varepsilon ́ \varsigma)$ which can be expected to recur in keeping with human nature

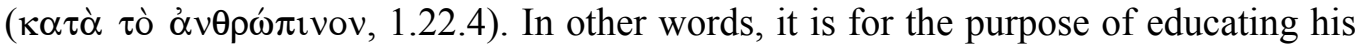
readership that Thucydides has woven his theory of human group behavior so deeply into these speeches (and into the History as a whole). And this education deals not

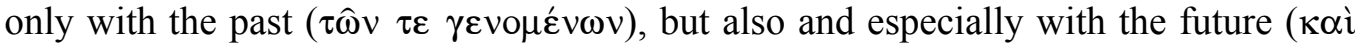
$\tau \hat{\omega} v \mu \varepsilon \lambda \lambda o ́ v \tau \omega \nu)$. Thucydides has sifted through the events of the Peloponnesian War, and has established the truth to the best of his ability, retaining only a vetted factual framework, and leaving us almost entirely dependent upon his judgment in many cases (cf. 1.22.2-3). It is for future events and history not yet written that the usefulness here described is also intended: the benefit of his "possession for all time" consists in no small measure in his imparting to his readers an ability to appreciate and apply the methodology of the psychological system he develops within the History's pages.

Thucydides does more here than show us the underlying dynamics of human nature at work. As we understand and vet the arguments presented in this antilogy according to the measuring rod he has provided, and as we ask ourselves the obvious questions of whether terror is really effective in the long run or whether clemency is truly a salutary policy for an empire, we begin to understand that Thucydides is telling us as much about the Athenians as he is about this particular historical crisis. The policy at issue is not being debated in a vacuum. This is a critical decision the Athenians must take. It is really first and foremost the orge of the Athenians that is in play, the expression of their physis in their desire to preserve freedom and empire amid necessity and chance. And it is to the hopes and fears of the Athenians that 
Thucydides has Cleon and Diodotus direct their arguments. The essence of Cleon's appeal to his countrymen is the practical hope of freedom from further rebellions if they accede to him and the fear of more if they do not, while Diodotus' appeal is essentially ethical, holding out the hope of amelioration in future revolts against the fear of implacable resistance if Cleon's advice is accepted. The entire reason why this debate even took place is, as Thucydides tells us, Athenian discomfort with the inhumaneness of their original decision, but Diodotus still needs to overcome their concerns about the possible inexpediency of clemency in order to prevail. We are left with the irony of Cleon arguing from justice for what is arguably unjust, and Diodotus arguing from expediency for what is arguably inexpedient (given Thucydides presentation of the facts in both cases). ${ }^{32}$

As the Athenians grapple with this decision, there is a further double irony here. They are considering the fate of an ally who has acted in a most "Athenian" way, throwing caution to the winds and trusting in hope regardless of the potential consequences (cf. 1.70, 4.65.4, 8.98.5). At the same time, they themselves are uncharacteristically wavering between two courses of action, each of which fills them with a degree of "un-Athenian" apprehension and fear of the possible consequences whether they choose to violate the restraints of practicality or those of ethical conduct. In this struggle of conscience versus self-will, Cleon and Diodotus serve as the two poles of the Athenians' collective gnome, each striving to direct the impulse of Athens' orge, each slanting the debate purely in terms of what may prove most persuasive. Thus, not only are the readers given to see the practical concerns of human nature which must lie behind a decision of this sort. As we are shown these applications of Thucydidean principles against the backdrop of the Athenian soul struggling with this critical choice, we also come to understand something of the challenge that confronts leaders of democracies, especially if they are truly attempting to lead. For it is in the totality of the triangulation of situation-speaker-audience that Thucydides show us what, in his view, "happened and is likely to happen again in the same or a similar way, in all human probability".

\section{BIBLIOGRAPHY}

Andrewes, A 1962. The Mytilene debate. Phoenix 16, 64-85.

Andrews, J A 2000. Cleon's hidden appeals (Thucydides 3.37-40). CQ 50, 45-62.

Badian, E 1992. Thucydides on rendering speeches. Athenaeum 80, 187-90.

Bicknell, P 1990. Thucydides, 1.22: A Provocation. AC 50, 172-78.

Bodin, L 1940. Diodote contre Cléon: Quelques aperçus sur la dialectique de Thucydide. REA 42, 36-52.

Bowersock, G W 1965. The personality of Thucydides. ANTR 25, 135-46.

Cogan, M 1981-1. The Human Thing. Chicago: University of Chicago Press.

Cogan, M 1981-2. Mytilene, Plataea and Corcyra. Phoenix 35, 1-21.

32 See Lewis 1992:383, and Kagan 1975:82-86, for discussions. Macleod 1978:77, states that Diodotus is trying to "lull the Athenians into comforting illusions about the attitude of their allies". Johnson 1990:57, calls Cleon's realpolitik "commonsensical". 
Connor, W R 1984. Thucydides. Princeton: Princeton University Press.

Crane, G 1996. The Blinded Eye. Lanham Md.: Rowman \& Littlefield Publishers.

Debnar, P 2000. Diodotus' paradox and the Mytilene debate (Thucydides 3.37-49). RhM 143, 161-178

Debnar, P 2001. Speaking the Same Language. Ann Arbor: University of Michigan Press.

Dover, K J 1973. Thucydides. Oxford: Clarendon Press.

Dover, K J 1974. Greek Popular Morality in the time of Plato and Aristotle. Oxford: Blackwell.

Edmunds, L 1975. Chance and Intelligence in Thucydides. Cambridge Mass.: Harvard University Press.

Finley, J 1947. Thucydides. Cambridge: Harvard University Press.

Flashar, H 1969. Der Epitaphios des Perikles. SHAW 1969, 1-56.

Garrity, T F 1998. Thucydides 1.21.1: Content and Form in the Speeches. AJP 119, 361-84.

Gomme, A W 1937. Essays in Greek Literature and History. Oxford: OUP.

Gomme, A W 1945. Historical Commentary on Thucydides v.1. Oxford: OUP.

Hornblower, S 1987. Thucydides. Baltimore: Johns Hopkins University Press.

Huart, P 1968. Le vocabulaire de l'analyse psychologique dans l'oevre de Thucydide. Paris: Klincksieck.

Huart, P 1973. ГN $\Omega$ MH chez Thucydide et ses contemporains. Paris: Klincksieck.

Hunter, V 1973. Thucydides: the Artful Reporter. Toronto: Hakkert.

Hunter, V 1977. The composition of Thucydides' History: a new answer to the problem. Historia 26, 269-94.

Hunter, V 1982. Past and Process in Herodotus and Thucydides. Princeton: Princeton University Press.

Hussey, E 1985. Thucydidean history and Democritean theory. In Crux Essays in Greek History presented to G.E.M. de Ste. Croix. Cartledge, P A and Harvey, F D (eds) 118-38.

Johnson, L M 1990. Rethinking the Diodotean Argument. Interpretation 18, 53-62.

Kagan, D 1975. The Speeches in Thucydides and the Mytilene Debate. YCS 24, 71-94.

Kennedy, G 1963. The Art of Persuasion in Greece. Princeton: Princeton University Press.

Lattimore, S Trans. 1998. Thucydides. Indianapolis: Hackett.

Lewis, D M 1992. The Archadamian War. In The Cambridge Ancient History: Vol. 5, The Fifth Century B.C. (Cambridge)

Luginbill, R D 1999. Thucydides on War and National Character. Boulder: Westview Press.

Luschnat, O 1970. Thukydides. In RE suppl. 12, c.1085-1354.

Macleod, C W 1978. Reason and necessity: Thucydides III 9-14, 37-48. JHS 98, 64-78.

Manuwald, B (1979). Der Trug des Diodotos (zu Thukydides 3,42-48), Hermes 107, 407-22.

Meister, C 1955. Die Gnomik im Geschichtswerk des Thukydides. Winterthur: Keller. 
Moraux, P 1954. Thucydide et la rhétorique: Étude sur la structure de deux discours (III, 37-48). LEC 22, 3-22.

Murari Pires, F 1998. The Rhetoric of Method (Thucydides 1.22 and 2.35). AHB 12, 106-12.

Müri, W 1947. Beiträge zur Verständnis des Thukydides. $M H$ 4, 251-75.

Nestle, W 1914. Thukydides und die Sophistik. NJA 10, 648-85.

Orwin, C 1994. The Humanity of Thucydides. Princeton: Princeton University Press.

Ostwald, M 1986. From popular sovereignty to the sovereignty of law. Berkeley: University of California Press.

Pohlenz, M 1919. Thukydidesstudien. NGG, 95-138.

Pouncey, P 1980. The Necessities of War. New York: Columbia University Press.

Reinhold, M (1985). Human Nature as Cause in Ancient Historiography. In The Craft of the Ancient Historian, ed. Eadie, J. and Ober, J. Lanham Md.: Rowman \& Littlefield Publishers.

Romilly, J de 1956. Histoire et raison chez Thucydide. Paris: Les Belles lettres.

Romilly, J de 1963. Trans. P. Thody Thucydides and Athenian imperialism. Oxford: Blackwell.

Rood, T 1998. Thucydides: Narrative and Explanation. Oxford: Clarendon Press.

Rutherford, R B 1994. Learning from history: categories and case-histories. In Ritual, Finance, Politics: Athenian Democratic Accounts presented to David Lewis 53-68. Oxford: Clarendon Press.

Ste Croix, G E M de 1972. The Origins of the Peloponnesian War. Ithaca: Cornell University Press.

Schmid, W and Staehlin, O 1948. Geschichte der griechischen Literatur. Munich: C. H. Beck.

Schneider, C 1974. Information und Absicht bei Thukydides. Göttingen: Vandenhoeck und Ruprecht.

Schram, J M 1965. Prodicus" "fifty-drachma show-lecture" and "the Mytilene debate" of Thucydides: an account of the intellectual and social antecedents of formal logic. ANTR 25, 105-30.

Shrimpton, G 1998. Accuracy in Thucydides. AHB 12, 71-82.

Smith, C F Trans. 1919. Thucydides. Cambridge MA.

Stadter, P A 1973. The Speeches in Thucydides. Chapel Hill: University of North Carolina Press.

Strassburger, H 1958. Thukydides und die politische Selbstdarstellung der Athener. Hermes 86, 17-40.

Swain 1993. Thucydides 1.22.1 and 3.82.4. Mnemosyne 46, 33-45.

Thompson, W 1969. Individual Motivation in Thucydides. C\&M 30,158-174.

Tompkins, D P 1993. Thucydides constructs his speakers: the case of Diodotus. EA 1, 1-9.

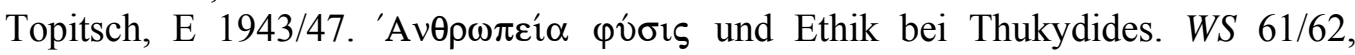
50-67.

Tsakmakis, A 1998. Von der Rhetorik zur Geschichtsschreibung: Das "Methodenkapitel" des Thukydides (1.22.1-3). RhM 141, 239-255. 
Wasserman, F M 1956. Post-Periclean democracy in action. The Mytilenean debate (Thuc. III, 37-48). TAPA 87, 27-41.

De Wet, B X 1963. Periclean imperial policy and the Mytilenean debate. AC, 6, 106-124.

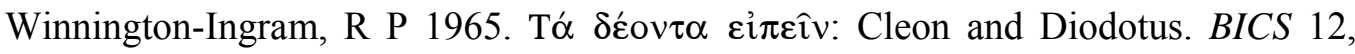
70-82.

Winton, R I 1999. Thucydides I.22.1. Athenaeum 87, 527-533.

Woodman, A J 1988. Rhetoric in Classical Historiography. London: Croom Helm. Wyatt, W 1996. Thucydides 1.22. Hyperboreus 2, 191-193. 